\title{
MOTYWIKA BIBLIJNA W TWÓRCZOŚCI POETYCKIEJ KAROLA WOJTYEY
}

Osobność miejsca zajmowanego w polskiej literaturze XX wieku przez twórczość poetycką Karola Wojtyły wydaje się faktem, potwierdzonym ustaleniami licznych badaczy ${ }^{1}$. Dotyczy to także odmienności jego wierszy wobec tzw. poezji kapłańskiej ${ }^{2}$, co wyraża się między innymi w specyficznym sposobie operowania przez Wojtyłę sygnałami biblijnymi i metodami przywoływania tradycji biblijnej. Czyni to zupełnie inaczej niż na przykład ks. Jan Twardowski, poeta czerpiący twórczą inspirację często i w sposób niezakamuflowany z wydarzeń opisywanych w Biblii, zazwyczaj w Nowym Testamencie. Celem niniejszego opracowania nie jest jednak pełny przegląd wszystkich sygnałów biblijnych obecnych w poezji przyszłego papieża. Uczyniła to już zresztą w dużej mierze Mirosława Ołdakowska-Kuflowa, dokonując całościowej prezentacji zawartych $\mathrm{w}$ jego dziele literackim odniesień do Biblii ${ }^{3}$. Zamiar badawczy niniejszego tekstu jawi się jako o wiele skromniejszy. Chodzi mianowicie bardziej o dokonanie klasyfikacji typów sygnałów biblijnych pojawiających się w utworach poetyckich Wojtyły i opis poetyckich chwytów zastosowanych dla ich wprowadzenia, niż o sporządzenie wyczerpującego katalogu biblijnych odniesień.

\footnotetext{
1 Na ten temat por. m.in. W. P. Szymański, Z mroku korzeni. O poezji Karola Wojtyły, Kalwaria Zebrzydowska 1989; K. Dybciak, Karol Wojtyła a literatura, [w:] Karol Wojtyła poeta, red. J. Głażewski, W. Sadowski, Warszawa 2006; Przestrzeń słowa, red. Z. Zarębianka, J. Machniak, Kraków 2006.

2 Na co zwraca uwagę m.in. Mirosława Ołdakowska-Kuflowa, Blask słowa. Inspiracja biblijna w twórczości literackiej Karola Wojtyły, Kielce 2004, s. 14.

3 Por. tamże.
} 
Odbiorcę spodziewającego się wyrazistej reprezentacji tradycji biblijnej $\mathrm{w}$ tej poezji czeka więc w tym względzie niejedno zaskoczenie. Pierwsze wiąże się z faktem, iż motywy biblijne zwykle nie pojawiają się w wierszach Wojtyły w sposób, by tak to nazwać, oczywisty, bezpośredni i naoczny, lecz oddziałują najczęściej niejako z ukrycia, tworząc swego rodzaju zaplecze sytuacyjne, treściowe bądź obrazowe dla lirycznych narracji. Wytwarza to swego rodzaju napięcie polegające na istnieniu $\mathrm{z}$ jednej strony oczywistej inspiracji biblijnej dającej się odkryć w wielu jego tekstach i głęboko przenikającej ich tkankę, $z$ drugiej na wąłłej obecności w wierszach Wojtyły pełnowymiarowej motywiki biblijnej, przywoływanej najczęściej jedynie w sposób fragmentaryczny, przy pomocy różnego rodzaju sugestii, nierzadko jednowyrazowych.

Wskazane zjawisko prowokuje pytanie nie tylko o rodzaje nawiązań biblijnych występujących w wierszach Wojtyły, ale przede wszystkim o poetyckie mechanizmy ich uruchamiania oraz o funkcje pełnione przez owe biblijne sygnały w strukturze znaczeniowej i obrazowej jego utworów.

Wpisane w wiersze Wojtyły nawiązania biblijne mają, jak zauważono, zróżnicowany charakter, pojawiają się na różnych poziomach tekstu ${ }^{4}$ i nie ograniczają się ani do biblijnych aluzji, ani - tym bardziej - do stylizacji ${ }^{5}$, w swej klasycznej postaci właściwie nieobecnej w analizowanych utworach. Pewien wyjątek w tym względzie stanowi młodzieńczy, napisany latem 1939 roku, wiersz Magnificat, odtwarzający strukturę wersyfikacyjną i brzmieniową maryjnego hymnu. Rzecz jednak $w$ tym, że ani bohaterem, ani podmiotem mówiącym tekstu nie jest w tym wierszu Maryja - jak w prototypowym hymnie - lecz sam poeta, wyśpiewujący chwałę Bogu za poezję, za dar natchnienia, nie tyle więc za „wielkie dzieła Bożej miłości”, ile za łaskę słowa poetyckiego i odnalezienie swego miejsca w polifonicznym chórze wielkiej tradycji polskiej literatury. W tym sensie więc przywołanie tradycyjnej formy maryjnego hymnu służy tu wyrażeniu treści całkowicie odmiennych od tych, które konstytuują pieśń Maryi.

Najprostszy sposób podziału obecnych w wierszach Wojtyły biblijnych nawiązań każe rozróżnić ich dwa zasadnicze rodzaje. Są to mianowicie nawiązania bezpośrednie (leksykalne, obrazowe, stylistyczne, rzadziej brzmieniowe, rzeczowe) oraz nawiązania pośrednie, które $\mathrm{z}$ uwagi na mechanizm odniesień słusznie będzie nazwać sygnałami czy nawiązaniami domyślnymi. Taki

\footnotetext{
4 Por. M. Ołdakowska-Kuflowa, Blask słowa..., dz. cyt., s. 19-35.

5 Zob. Stylizacja biblijna, [w:] Encyklopedia religii, red. T. Gadacz, B. Milerski, Warszawa 2007, t. CD ROM.
} 
sposób przywołań oznacza po pierwsze zasadność ostrożności w używanym $\mathrm{w}$ tym zakresie nazewnictwie. Wydaje się zatem, iż z uwagi na zróżnicowanie rodzajów biblijnych znaków w wierszach Karola Wojtyły lepiej używać określeń jak najbardziej pojemnych, mieszczących w sobie całą gamę możliwych typów odniesień. Proponuję więc, by mówić raczej o sygnałach biblijności czy o śladach biblijnych niż o biblijnych motywach, nawiązaniach, tradycji czy inspiracjach, choć dwa ostatnie pojęcia z pewnością okażą swoją przydatność. Wydaje się mianowicie, że jako najbardziej ogólne, konstytuują ten poziom, na którym dochodzi do przejawiania się poprzez różnego typu zabiegi biblijnego charakteru pisarstwa Wojtyły. Innymi słowy, tradycja biblijna obecna w jego utworach daje się rozpoznać przy pomocy całego szeregu detalicznych sposobów jej uruchamiania od posłużenia się jakimś motywem, po najbardziej ukrytą, ale najważniejszą sferę aksjologii i postaw, zakorzenionych w zarówno w Dekalogu, jak i przede wszystkim w Chrystusowych błogosławieństwach oraz w przykazaniu miłości Boga i bliźniego. Tego rodzaju odwołania można by nazwać odwołaniami białymi. Rozumiem przez to, iż nie przejawiają się żadnymi rozpoznawalnymi nawiązaniami do konkretnych fragmentów Pisma Świętego ani o charakterze stylistycznym, ani obrazowym. Prezentowane wszakże przez bohaterów postawy są umocowane w świecie biblijnej aksjologii, stanowią jej wyraz i przynoszą literackie świadectwo praktycznego zastosowania w życiu podstawowych wskazań wynikających z wiary - dla której oparcie, jedno z fundamentalnych, wyznacza przekaz zawarty w Biblii. Tego rodzaju wariant białych odwołan do Biblii, poprzez nawiązania aksjologiczne przekazywane „behawioralnie”, w drodze prezentowanych przez bohaterów wyborów i postaw, daje się zauważyć na przykład w Rozważaniu o ojcostwie czy w Rozważaniu o śmierci, a także w poemacie Stanisław, nie mówiąc o dramatach, w których dochodzi najsilniej do głosu, lecz które nie są przedmiotem zainteresowania niniejszego szkicu. Tytułem dygresji warto jednak zauważyć, iż analiza Brata naszego Boga przeprowadzona pod kątem takich aksjologicznych nawiązań mogłaby okazać się szczególnie interesująca.

Po drugie, powiedziane powyżej oznacza, że rzeczone sygnały biblijne $\mathrm{w}$ utworach poetyckich przyszłego papieża pojawiają się niekiedy w planie niejako pozajęzykowym, czy lepiej: pozatekstowym, i te, jak się wydaje, stanowią wariant najbardziej oryginalny, niespotykany raczej u innych poetów. Tego rodzaju sytuację mam też na uwadze, posługując się terminem odniesień domyślnych. Można również mówić o swego rodzaju gradualności w zakresie obecności różnych typów sygnałów biblijnych w utworach poety. Mam na myśli zjawisko polegające na czymś, co można by nazwać odwróceniem pro- 
porcji, a wyrażające się w fakcie, iż nawiązania bezpośrednie, oczywiste i łatwo rozpoznawalne odgrywają $\mathrm{w}$ utworach Wojtyły mniejszą rolę semantyczną i pojawiają się rzadziej od sygnałów bardziej zakamuflowanych, do których odkrycia nieodzowna jest znajomość Biblii i pewna kultura religijna.

Do najczęściej używanych przez poetę odniesień bezpośrednich należy posługiwanie się imionami biblijnych postaci. Wczesne, juwenilne jeszcze dramaty Hiob i Jeremiasz, wskazujące już samymi tytułami na bohaterów biblijnej sceny, są tej metody najbardziej oczywistą ilustracją. Należący do juwenilnej twórczości utwór Magnificat w tym zakresie byłby natomiast nieco zwodniczy. Tytuł tekstu wskazuje bowiem na Maryję, natomiast, jak zauważono, rzeczywistym bohaterem wiersza jest sam poeta. Ta modyfikacja nie jest tu połączona $\mathrm{z}$ wprowadzeniem jakichkolwiek treści kłócących się $\mathrm{z}$ ideami zawartymi $\mathrm{w}$ hymnie Magnificat, nie powstaje zatem efekt dysonansu pomiędzy przywołaną konwencją a zawartością wypowiedzi głównego bohatera, niemniej warto odnotować to przesunięcie semantyczne, ponieważ wydaje się ono czymś rzadko spotykanym w poezji Wojtyły. Nieco inny, i nieco bardziej skomplikowany mechanizm przywołania postaci przynosi kolejny, pochodzący z 1950 roku, wiersz zatytułowany Matka. Tutaj mamy do czynienia ze znakiem po części podwójnym, wskazującym na osobę Maryi poprzez przypisywany jej w tradycji i łączony z jej postacią tytuł Matki oraz poprzez stylizowaną parafrazę hymnu maryjnego, którego wprowadzenie do utworu stanowi dodatkowy sygnał biblijny, intensyfikujący pole odniesień. Wypowiedź Maryi w drugim fragmencie trzeciej części wydaje się delikatną aluzją do owego hymnu, w jego wersji zapisanej w Ewangeliach. Mówiłabym tu jednak raczej o pewnej paralelności w zakresie wygłoszonych treści niż o prostym naśladownictwie stylistycznym. Poszczególne sekwencje tej części poematu Matka wydają się przeto treściową parafrazą maryjnej pieśni uwielbienia, odsyłając dzięki charakterowi wypowiedzi i postawie bohaterki do ewangelicznego pierwowzoru. Powyższy przykład pokazuje, jak wielokształtne bywa w przypadku tej poezji oddziaływanie pojedynczego, wydawać by się mogło jednoznacznego i nieskomplikowanego sygnału biblijnego, a także w jaki sposób następuje migotliwe przenikanie się sygnałów bezpośrednich i niebezpośrednich.

Sygnałami bezpośrednimi będą też pojawiające się w świecie przedstawionym utworów rekwizyty, na przykład dzban, studnia, skała, jarzmo, krzyż, odsyłające do konkretnych perykop ewangelicznych. Sygnałem bezpośrednim o bardziej skomplikowanym statusie są wspomniane i często stosowane przez autora motta. $\mathrm{Z}$ jednaj strony, z pewnością mamy w tym 
wypadku do czynienia z odniesieniami jawnymi, przywoływanymi w postaci dosłownych cytatów. Z drugiej wszakże strony, motto funkcjonuje poza tekstem samego utworu, nie stanowi jego immanentnej części, stąd sygnał w postaci cytatu biblijnego umieszczonego poza głównym tekstem staje się wobec tego tekstu sygnałem pośrednim w tym sensie, iż w tekście właściwym go po prostu nie ma. Takie biblijne motto promieniuje więc na tekst utworu spoza niego, z zewnątrz, nadaje kierunek interpretacji, dostarcza materiału potrzebnego do rekonstrukcji lirycznej ramy, samo jednak nie należy do tkanki danego tekstu. Warto więc podkreślić, że wszystkie wymienione bezpośrednie sygnały zazwyczaj funkcjonują $\mathrm{w}$ powiązaniu $\mathrm{z}$ sygnałami pośrednimi, danymi nie wprost. Za specyficzną cechę twórczości literackiej Wojtyły uznać należy, jak sądzę, interakcje istniejące pomiędzy sygnałami bezpośrednimi oraz pośrednimi i następującą w wyniku owego powiązania ich wzajemną intensyfikację.

$\mathrm{Z}$ takim więc niebezpośrednim sposobem uruchomienia sygnału biblijnego można się spotkać między innymi w Pieśni o blasku wody. Utwór został wprawdzie poprzedzony krótkim mottem z Ewangelii św. Jana, wskazującym na konkretne wydarzenie ewangeliczne, do którego odnosi się zawarte w poemacie rozważanie, w tekście utworu wszakże nie zostaje ono odtworzone. Przywoływane zdarzenie, w tym wypadku jest to rozmowa Jezusa z Samarytanką, promieniuje na tekst niejako spoza utworu, wyznacza ramę sytuacyjną dla podjętej w nim medytacji. Kolejne sygnały nawiązań biblijnych unaoczniają się w rzeczonym poemacie poprzez tytuły poszczególnych części pieśni, w których pojawiają się jednowyrazowe aluzje, ponownie odsyłające do Janowej narracji. Przywołane rekwizyty (studnia, dzban), operowanie aluzją sytuacyjną, wskazanie na osobę (Samarytanka) pozwalają jednoznacznie umieścić prowadzoną medytację w kontekście relacji o spotkaniu Chrystusa $\mathrm{z}$ kobietą z Samarii. Właściwy tekst natomiast przynosi prowadzone częściowo z perspektywy Samarytanki rozmyślanie o charakterze duchowym osnute na kanwie zdarzeń skądinąd wiadomych czytelnikowi, zdarzeń, które jednak w samym rozważaniu kobiety nie zostają wspomniane. W ten sposób narracja Wojtyły, wpisując się przecież w kontekst ewangeliczny i czerpiąc z biblijnego przekazu, unika dosłowności, buduje też jak gdyby apokryficzny ciąg dalszy, skupiając się na jednostkowym przeżyciu egzystencjalnym i duchowym wybranej postaci, która opowiada o swoim doświadczeniu spotkania i rozmowy z Mistrzem. Zastosowana metoda uruchomienia biblijnego śladu wydaje się wykazywać pewną analogię do znanej w tradycji Kościoła formy modlitwy, zwanej lectio divina. Umieszczone w utworze Wojtyły rozważanie może mia- 
nowicie być potraktowane jako owoc tego rodzaju praktyki. Prawomocność tego rodzaju analogii znajduje dodatkowe potwierdzenie w medytatywnym charakterze dyskursu poetyckiego Wojtyły, wskazywanym przez badaczy jako jego cecha dystynktywna ${ }^{6}$.

Rozważanie bohaterki zostaje przy tym ukształtowane w taki sposób, iż respektując podmiotowość jej relacji, zarazem odsłania sensy uniwersalne, przynosząc jednocześnie pewien model głębokich odniesień człowieka do Boga i do drugiego człowieka. Warto zauważyć, że w lirycznej narracji poematu ani raz nie pada samo imię Jezusa, nie mówi się też bezpośrednio o Bogu. Boskość osób sugeruje jedynie operowanie dużymi literami w zaimkach osobowych. Zwracam na to zjawisko uwagę (podobnie rzecz wygląda w Pieśni o Bogu ukrytym), gdyż zastosowana metoda przyczynia się do uniwersalizacji przesłania utworu, implikującego możliwość dwojakich odczytań - bardziej religijnego, adresowanego do odbiorcy zdolnego rozpoznać ukryte w tekście sygnały biblijne i odnieść je do wytwarzanych przez biblijny kontekst sensów oraz odczytania o charakterze bardziej egzystencjalnym, przeznaczonego dla czytelnika nieposiadającego potrzebnej kompetencji kulturowo-religijnej, pozwalającej mu dotrzeć do warstwy generowanej przez przywołania biblijnych sygnałów i niesionych przez nie znaczeń. Trzeba też zaznaczyć, iż gdyby w tekstach pojawiały się pełnowymiarowe jawne sygnały biblijności w miejsce zastosowanej przez autora metody przywołań cząstkowych oraz niebezpośrednich, wówczas wspomniana wyżej i niezwykle dla utworów Wojtyły istotna płaszczyzna sensów uniwersalnych ${ }^{7}$ nie mogłaby powstać. Teksty traciłyby zatem swoją dwuwymiarowość i dawałyby się odczytywać wyłącznie w kluczu religijnym. Zastosowany przez Wojtyłę sposób uruchamiania sygnałów biblijnych, niezwykle powściągliwy i dyskretny oraz przewaga odniesień domyślnych i pośrednich nad sygnałami jawnymi przyczyniają się do wzbogacenia semantycznego jego tekstów, nadają im także rys swoistego ekumenizmu, jak też znacząco powiększają krąg adresatów, wśród których z powodzeniem mogą się znaleźć również niekatolicy i osoby niewierzące. Jest to też metoda, dzięki której dokonuje się swoisty przekład przekazu biblijnego na przekaz o charakterze uniwersalnym, $\mathrm{z}$ równoczesnym zachowaniem całej istoty ewangelicznego przesłania.

$6 \quad$ Por. m.in. Z. Zarębianka, Medytacja znaczeń. O specyfice dykcji poetyckiej Karola Wojtyły, [w:] Karol Wojtyła - poeta, dz. cyt., s. 251-257.

Na ten temat zob. Z. Zarębianka, Medytacja znaczeń. O specyfice dykcji poetyckiej Karola Wojtyły, dz. cyt. oraz M. Ołdakowska-Kuflowa, Blask słowa..., dz. cyt. 
$\mathrm{Z}$ analogicznym sposobem wprowadzania sygnałów biblijnych poprzez tworzenie z perspektywy wybranej biblijnej postaci opowieści apokryficznej w oparciu o nieujawniony wprost fragment biblijnego tekstu przynosi wspomniany już wyżej poemat Matka. Bohaterką poematu jest Matka Boża, podejmująca (podobnie jak w poprzednim utworze czyniła to Samarytanka) wewnętrzne rozmyślanie nad wydarzeniami z jej życia: zwiastowaniem, narodzinami Jezusa, Jego życiem i dorastaniem w Nazarecie, relacją z Janem. Żadne wszakże z wymienionych wydarzeń nie zostaje w utworze wymienione, stanowią one domyślny kontekst medytacji Matki, kontekst wymagający dopiero rozpoznania przez odbiorcę i włączenia go w proces odczytywania utworu. Kolejny paradoks, który się zaznacza przy tego rodzaju metodzie uruchamiania biblijnych nawiązań, wyraża się w fakcie, że to, co werbalnie nieobecne w tekście utworu, wyznacza jego zasadnicze znaczeniowe jądro. Na sposób kreacji postaci Matki Jezusa (nazywanej po prostu Matką!) z ukrycia niejako oddziałuje ewangeliczna uwaga, iż Maryja „rozważała wszystkie te słowa w swoim sercu". Ta właśnie glosa wydaje się nie tylko wpływać na ukształtowanie postaci Maryi, ale i generować całe jej hipotetyczne rozmyślanie, możliwe w kontekście wizerunku przekazanego w Ewangeliach, nieprzywoływanego jednak ani razu w trybie bezpośrednim w tekście utworu.

Podobną do ukazanej poprzednio metodę wpisywania się w tradycję biblijną poprzez dopisywanie domniemanych dalszych ciągów opowieści, tworzących głęboką medytację zastosował Wojtyła także w Profilach Cyrenejczyka. Również i tutaj tekst został poprzedzony odnośnym mottem $\mathrm{z}$ Ewangelii, pozwalającym na wyznaczenie sytuacyjnego kontekstu podjętego przez poszczególnych bohaterów rozważania. W Profilach następuje też znamienne powiększenie liczby osób o postaci niewystępujące w narracjach ewangelicznych, a będące nośnikami postaw i zachowań najbardziej według autora typowych, mających swoje umocowanie i swój pierwowzór w reakcjach postaci znanych z relacji Ewangelistów i uwzględnionych przez Wojtyłę w jego utworze. Są to Magdalena oraz Szymon z Cyreny. Bardziej niejasny jest status Niewidomego oraz Dzieci. Z jednej strony, można widzieć w ich postaciach jakąś łączność z ewangelicznym niewidomym oraz z występującymi w przypowieści Jezusa dziećmi, stawianymi za wzór właściwej postawy w odniesieniach do Boga. W tym sensie wolno byłoby traktować sylwetki wymienionych bohaterów jako inspirowane przekazami Ewangelii. Z drugiej strony, podobieństwo do postaci ewangelicznych (szczególnie w wypadku niewidomego) wydaje się na tyle odległe, iż nie pozwala na jednoznaczne stwierdzenie bezpośredniego wpływu biblijnego. 
Innym rodzajem zjawisk ilustrujących sposób uruchamiania tradycji biblijnej w tekstach poetyckich Wojtyły jest promieniowanie jeszcze bardziej ukryte. W wersjach omówionych wyżej polegało ono na oddziaływaniu na tekst sensów zawartych w pochodzącym z Biblii motcie lub też, w drugiej opcji, na semantycznym wpływie pojedynczego sygnału biblijnego, sugerowanego przy pomocy jednego znaczącego wyrazu pełniącego rolę swoistego pars pro toto. Jeżeli więc na przykład w Pieśni o Bogu ukrytym pojawia się wzmianka o „maleńkiej celce”, można jednoznacznie przyporządkować ją wypowiedzianemu przez Chrystusa zaleceniu na temat warunków potrzebnych do modlitwy ${ }^{8}$. W tym momencie, dla kwestii metod nawiązań biblijnych, marginalne wydaje się spostrzeżenie, iż w rzeczonej sekwencji Wojtyłowego tekstu dochodzi do odwrócenia ewangelicznej sceny. W perykopie ewangelicznej zalecenie Jezusa dotyczy człowieka, w utworze upodobanie do miejsc bezludnych i pustych przypisywane jest Bogu, co wszakże w swojej ogólnej wymowie pozostaje w pełnej zgodności z kreowanym w Ewangeliach wizerunkiem Chrystusa, chętnie i często oddalającego się na samotną modlitwę. Chodzi mi jednak o jeszcze inny wariant, gdy domniemany fragment Ewangelii stojący na zapleczu danej sceny lirycznej nie jest sygnalizowany w żaden widoczny sposób. Jako przykład można przytoczyć fragment sekwencji 11 z Pieśni o słońcu niewyczerpanym: „[...] i poznany wzajemnie poznaje i wzajemną obfitością tchnie", pod spodem którego odkryć się dają dwie ewangeliczne glosy: „Ja i Ojciec jedno jesteśmy” ( $\mathrm{J} 10,30)$ oraz „Kto zna Mnie, zna także i Ojca" (Mt 11, 25; Łk 10, 21). Podobna sytuacja zachodzi w kilkakrotnie wymienianym poemacie Matka. Całe jej rozmyślanie uznane może być za ilustrację a zarazem rozwinięcie ewangelicznej charakterystyki Maryi danej w lapidarnej formule „I rozważała wszystkie te słowa w swoim sercu" (por. Łk 2, 19). Podobnych miejsc w całej twórczości Wojtyły, zarówno poetyckiej, jak i dramaturgicznej, znaleźć można sporo' ${ }^{9}$. Istotne wydaje się, iż owe niewypowiedziane glosy ewangeliczne $\mathrm{z}$ „zaplecza”, z tylnego planu oddziaływujące na tekst wskazują na rdzeń sensu danego utworu lub jego części. Odkrycie ich zatem posiada fundamentalne znaczenie dla prawidłowej, a przede wszystkim całościowej jego interpretacji.

Dokonany przegląd głównych rodzajów odniesień biblijnych obecnych w utworach poetyckich Wojtyły oraz metod ich uruchamiania w tekstach pozwala stwierdzić ich wieloaspektową różnorodność wyrażającą się zarówno

\footnotetext{
8 Ty zaś, gdy chcesz się modlić, wejdź do swej izdebki. Por. Mt 6, 6.

9 Por np. utwory: Kamieniołom, Pieśń o blasku wody czy Promieniowanie ojcostwa.
} 
w zróżnicowaniu typologicznym, jak i w bogactwie mechanizmów rządzących uobecnianiem owych sygnałów w materii wierszy. Daje się zauważyć się znacząca przewaga sygnałów odsyłających do Nowego Testamentu, szczególnie do Ewangelii, najczęściej do Ewangelii św. Jana. Wybór tej właśnie narracji spośród innych ksiąg Ewangelii można uzasadnić mistycznym nacechowaniem omawianej twórczości, stanowi on zarazem argument na rzecz jej mistycznych walorów. Wreszcie zwraca też uwagę prezentowany we wszystkich tekstach pozytywny i przytakujący stosunek do tradycji biblijnej. To akurat nie powinno być zaskoczeniem, niemniej na tle strategii wykorzystywania biblijnych sygnałów przez innych twórców polskiej literatury XX wieku Wojtyłowa strategia przytaknięcia w połączeniu z niespotykaną dyskrecją w operowaniu biblijnymi znakami jest jednym z czynników odmienności jego poetyckiej drogi, stanowi też o niepowtarzalności jego poetyckiego głosu, przyczyniając się do wytworzenia specyficznych i tylko tej poezji właściwych jakości. 